\title{
Origin of the
}

\section{Chattanooga Shale}

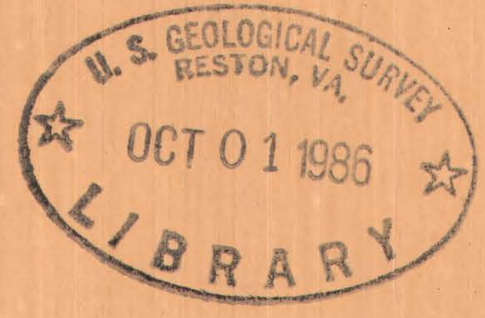

\section{Trace Elements Investigations Report 237}

OF $10-7-52$

(als.) I \& A Bulle, vi64, mo,12, pt,2:1529. 1953

UNITED STATES DEPARTMENT OF THE INTERIOR

GEOLOGICAL SURVEY 
UNCL A S S IF IE D

Geology - Mineralogy

This document consists of 22 pages, Series A.

\section{UNITED STATES DEPARTMENT OF THE INTERIOR}

GEOLOGICAL SURVEY

ORIGIN OF THE CHATTANOOGA SHALE*

By

L. C. Conant

July 1952

Trace Elements Investigations Report 237

This preliminary report is distributed without editorial and technical review for conformity with official standards and nomenclature. It is not for public inspection or quotation.

-This report concerns work done on behalf of the Division of Raw Materials of the U. S. Atomic Energy Commission 
USGS - TEI Report 237

GEOLOGY - MINERALOGY

Distribution (Series A)

No. of copies

A merican Cyanamid Company, Watertown. . . . . . . 1

Argonne National Laboratory . . . . . . . . . . . . 1

Atomic Energy Commission, Washington .. . . . . . . 2

Carbide and Carbon Chemicals Company, Y-12 Area . . . . 1

Colorado Raw Materials Office (F. H. MacPherson). . . . . 1

Division of Raw Materials, Grand Junction . . . . . . . 1

Division of Raw Materials, Grants . . . . . . . . . 1

Division of Raw Materials, Denver. . . . . . . . . 1

Division of Raw Materials, Hot Springs . . . . . . . 1

Division of Raw Materials, New York. . . . . . . . . . 6

Division of Raw Materials, Salt Lake City . . . . . . . 1

Division of Raw Materials, Richfield . . . . . . . . . 1

Division of Raw Materials, Butte . . . . . . . . 1

Division of Raw Materials, Washington . . . . . . . . 3

Division of Research, Washington ............ . . 1

Dow Chemical Company, Pittsburg . . . . . . . . . . . . 1

Pennsylvania State College, State College. . . . . . 1

Technical Information Service, Oak Ridge. . . . . . . . 6

U. S. Geological Survey:

Mineral Deposits Branch, Washington. .. . . . . . 2

Geochemistry and Petrology Branch, Washington. . . . . . 1

Geophysics Branch, Washington . . . . . . . . . . 1

Alaskan Geology Branch, Washington. . . . . . . . . . 1

Fuels Branch, Washington ... . . . . . . . . . . . 3

V. E. McKelvey, Washington . . . . . . . . . . . . 1

L. R. Page, Denver . . . . . . . . . . . . . . . . 1

R. P. Fischer, Grand Junction . . . . . . . . . . . . 1

A. E. Weissenborn, Spokane. . . . . . . . . . . . 1

J. B. Cathcart, Plant City. . . . . . . . . . . . . . 1

J. F. Smith, Jr., Denver . . . . . . . . . . . . . . 1

N. M. Denson, Denver . . . . . . . . . . . . . . . 1

R. W. Swanson, Spokane . . . . . . . . . . . 1

C. B. Read, Albuquerque . . . . . . . . . . . . . 1

A. H. Koschmann, Denver ... . . . . . . . . . . 1

E. H. Bailey, San Francisco . . . . . . . . . . . . . 1

C. A. Anderson, Tucson ... . . . . . . . . . . 1

David Gallagher, Joplin . . . . . . . . . . . . 1

Carl Dutton, Madison . . . . . . . . . . . . 1

R. A. Laurence, Knoxville . . . . . . . . . . . . . 1

R. J. Roberts, Salt Lake City. . . . . . . . . . . 1

L. C. Conant, University, Alabama . . . . . . . . 5

TEPCO, Washington ... . . . . . . . . . 15

(Including master) 
ORIGIN OF THE CHATTANOOGA SHALE

By L. C. Conant

(Read to Kentucky Geological Society meeting on November 2, 1951)

ABSTRACT

Tonight I will try to present to you the chief facts we have observed that have a bearing on the old problem of how the black shales originated. Some of the ideas have been used before, and some are new. Some of those that have been used before, have been used to support arguments for both shallow and deep water, yet I shall use them again and try to show why our use of them in support of shallow water is justified, and the other fellow's use of them in support of deep water is not justified.

These conclusions are strictly our own. Early in our studies we gave serious consideration to deep-water possibilities, but always we ran into such highly improbable circumstances and implications that we were forced to abandon them. The shallow-water theory seems to encounter no such formidable obstacles. We know of no facts that are incompatible with a shallow-water theory; we think that all known facts lend themselves to such an explanation; and we believe that a shallow-water explanation of these black shales is the simpler and sounder of the alternatives. 
It is a real pleasure to be here tonight and have the opportunity to discuss with you one of the long-standing problems of our profession- - the black shale problem. As many of you know, the black shale deposits, especially the marine ones of North America and other parts of the world, have long provoked widely different opinions as to their origin. Also, the Chattanooga shale and its correlates, the New Albany and Ohio shales, which are on three sides of us here at Lexington, have provoked differences of opinion as to age. To name the participants in this long standing controversy would be to call the roll of many of the famous stratigraphers and other geologists. Tonight I do not propose to call such a roll nor to strain your patience with a lecture on the history of the controversy, though such a lecture by one properly qualified would be most interesting.

Before proceeding, it may be well to clarify the term black shale. As commonly used, the term refers to a shale that has an abundance of bituminous matter. Such rocks, when hit with a hammer, commonly emit a distinctly petroliferous odor. Carbonaceous shales, such as those associated with coals, are also black, but for some reason not easy to explain they are not included in the term "black shale." I suppose it is almost fair to state that the term black shale is a couple, used practically as one word, and having a distinct connotation, just as I am repeatedly reminded in the South that damyankee has long been considered one word, having a distinct connotation. This discussion tonight deals with bituminous shales, commonly called black shales.

Although I have promised not to discuss the history of the black shale controversy, it will be well to mention its chief elements.

At least 75 years ago geologists studying the Chattanooga and related black shales were speculating on their age. It has been generally agreed that their age is Devonian or Mississippian, but there the agreement ends. Some investigators have concluded that they are of Late Devonian age. Others have been convinced of their Mississippian age. Still others have thought that they are partly Devonian and partly Mississippian in age. And a fourth group has thought that the shale has different ages in different places. Each of these ideas has merit, but many investigators have attempted to apply their findings too widely, or have been unaware of special conditions.

Perhaps the chief reason for the disagreement on age is the paucity of fossils with which 
paleontologists have been accustomed, such as brachiopods, trilobites, cephalpods, corals, and the like. Conodonts have long been recognized in the shale, but only in the last 25 years have they been much used for correlation. John Huddle, in 1933 and 1934, was one of the early workers to use conodonts for correlation, when he subdivided the New Albany shale, and assigned a Late Devonian age to all but the upper 5 or 10 feet. In 1946 Guy Campbell published his regional correlation which, like most geologic reports, differed at least in detail from earlier interpretations. He assigned much of the Chattanooga in Tennessee to the Mississippian.

During the present investigation W. H. Hass, of the U. S. Geological Survey, has been making a painstaking study of the age of the Chattanooga shale and the associated rocks, and of their correlation with strata in other areas. Those studies have been chiefly on the conodonts. He has found that most of the Chattanooga shale of central Tennessee is of Late Devonian age, and that the 30 or 35 feet of shale seems to represent most of Late Devonian time--a span of several million years. For me to try to give you further details of that complex study by Hass, which is still in progress, would be both premature and presumptious, so I shall not discuss the age problem further.

As to origin, it may be briefly stated that many writers on the subject have thought that the black muds accumulated in deep water; others have attributed them to shallow water. Most writers, unfortunately, have left their readers to guess what was meant by such terms as deep and shallow, but it seems fair to assume that most geological writers think of deep water as at least a few hundred feet deep, or at least beyond the depths where wave action disturbs the bottom sediments. Recent submarine photographs, however, have revealed distinct evidence of current action on the bottom muds to depths of at least 3,000 feet. Other studies have cast doubt on the depths to which waves disturb the muds, and it may be that all of us will have to re-examine our concepts of wave base. Belief in a deep-water origin of black shale in general was prompted by its fine grain and its widespread distribution, and that belief was strengthened by the dredgings of black mud from the floor of the Black Sea at depths of some 6,000 feet.

Other writers have pointed to the present-day accumulation of black mud in such places as the Baltic Sea and the Norwegian fjords, where the water is only a few feet or a few tens of feet deep, and they have reasoned that the ancient black muds could also have accumulated in water of comparable depths. 
Unfortunately, the black shales contain little evidence within themselves as to depth of water in which the muds accumulated. Fossils are scant, ripple marks and mud cracks are uncommon at best, interbedded sediments of types that would reveal the environment are not plentiful, and writers have drawn their conclusions by analogies of questionable worth, from fragmentary and unconvincing evidence within the shale, or by some indirect approach. Within the last few weeks John L. Rich has presented a new line of reasoning in support of a deep-water origin. Thus the old controversy lives on, and tonight I shall present other ideas.

We approached the problem 4 years ago with no pre-conceived theories. As for myself, I confess that I was familiar with the black shale problem only by name. With the probable exception of Hass, other members of the USGS party were equally unbiased. If Hass had any firm conviction as early as 1947 concerning the origin of the black shale, he never tried to sell the rest of us that conviction. Thus, I think it is fair to state that when we undertook our detailed investigation of the black shale, most of us were somewhat like babes in the woods, little aware of the darkness and pitfalls confronting us. I do not recommend that geological problems in general be attacked by such an innocent and unsuspecting personnel, and I point out our innocence only to show you that the conclusions we have drawn are based largely on our own observations and reasoning.

Before getting further into the topic of this evening, it may be well to confide in you what we have concluded, that you may be better able to evaluate the facts that I shall present, and the reasoning that will follow. All of us who have worked much on the project are convinced that the Chattanooga and related black shales accumulated in shallow water, very likely less than 100 feet deep--in some places only a few feet deep.

I should tell you, in case you do not know it, that our investigation was undertaken at the request and with the support of the Atomic Energy Commission, because of the uranium content the black shales are known to have. One of the aims of the investigation was to obtain sufficient samples for assays to learn the facts concerning the vertical and horizontal distribution of the uranium, to learn if the distribution is at all uniform or is hopelessly irregular, and to find where the uranium content is greatest, in the hope that minable areas might be found. With such an assignment, we were at liberty to make a thorough 
investigation of the shale. As the black shales have long been known to be potential oil shales, we naturally considered that phase in oul: study, for, after all, one or more marketable byproducts could well control the economic feasibility of mining the shale for uranium.

We started our work on the eastern edge of the Nashville Basin of Tennessee, chiefly because previous reconnaissance studies of the Chattanooga and related shales in Kentucky, Tennessee, and Alabama had suggested that the highest uranium content might be in that area. The available data at that time, however, were far too fragmentary to verify that suggestion or even to permit a reasonable estimate of the uranium content of the shale in appreciable areas. Our most intensive studies were also on the eastern edge of the Nashville Basin, but we extended those, in somewhat less detail, entirely around the Basin, to the Sequatchie Valley, the Cumberland Valley of southeastern Kentucky, and to scattered other areas, including a few places on the rim of the Bluegrass region. Most of the following discussion is necessarily based largely on our more detailed work in central Tennessee, though much of it seems applicable to the black shale over large areas.

Associated with the project from the beginning, and intermittently to the present, has been Wilbert H. Hass, whose full-time intensive studies of conodonts, and familiarity with black shales over much of the United States, made him an invaluable asset. Vernon E. Swanson came to the project later, but his work has contributed materially to the conclusions we now hold. I will not burden you with a list of the 15 or 20 other people who worked on this project for a longer or shorter time, though I must mention four others with whom some of you are acquainted. Raymond C. Robeck investigated several areas in Kentucky, notably that part of the Cumberland Valley now inundated by the waters of Wolf Creek Resevoir, and several areas around the Bluegrass region. In this work, Mr. Dan Jones and Dr. McF arlan were taken into our confidence in what was at that time a strictly classified project; Dan Jones gave Robeck much time and help in finding and visiting areas that appeared to be worth study. Your Secretary, Jack Johnston, had the questionable privilege of working with us six weeks one summer when our task was to collect hundreds of samples by laboriously cutting them from the outcrops--the fresher and tougher the rocks the better. Such samples were collected in the rnist of waterfalls, from vertical gorge falls, and from highway cuts, by use of geologic hammers, wedges, and brute force, at the cost of innumerable hammer handles, 
uncounted knuckles barked by flying chips of shale and steel, and untold minor hardships. Jack did so well pounding out shale that he was later given a job digging out coal samples in Kentucky. Bill Heck, who was formerly with the USGS coal party in Kentucky, also had his start on the black shale, where he, too, showed that he would make a good coal sampler. Larry Shirley, whom many of you know, not only had the privilege of pounding out samples for several months, he also worked at our office at Tuscaloosa, and had the fun of splitting open thousands of pieces of shale and scanning their surfaces under a binocular microscope in search of conodonts that might be worth further study by Hass.

For various purposes, we collected thousands of samples from hundreds of outcrops. We measured several outcrops in detail, recording beds having a thickness of one-hundredth of a foot or more, and decribing their colors and other noteworthy characteristics. All the other outcrops were measured carefully, and studied in more or less detail. The upper and lower contacts were studied, as were any overlying or underlying materials that promised to shed light on the age and origin of the shale. We gave considerable attention to the 2 or 3 feet of material that customarily overlies the black shale, as this unit is genetically associated with the Chattanooga shale. This overlying unit has commonly been known as the Maury.

Thus far I have talked chiefly concerning why and how we worked. Now I shall give you some of the facts we learned concerning the Chattanooga shale, and from there proceed to some of the inferences we have drawn from those facts.

To this audience I hardly need dwell on the fact that the black shales are nearly massive when fresh, but fissile when weathered. Careful observation shows that what appears to be a massive black shale commonly contains minute partings and thin beds of silt, fine sand, and bitumen, has stringers of pyrite or marcasite, and locally contains bones, wood, and phosphate nodules.

Spores and other minute parts of marine plants are fairly abundant in the shale. At one place we partially disinterred a mass of bones, and sent them to Mr. D. H. Dunkle, of the U. S. National Museum, for possible identification. In this collection Dunkle recognized probable parts of the armored fish Dinicthys terrelli, and parts of two species of early ray fin fishes (Rhadinicthys antiquus and $\mathrm{R}$. devonicus.) All of these fishes are supposedly of Late Devonian age.

Conodonts are common in the shale, and are so abundant in some laminae as to suggest either 
that hardly any other material was accumulating on the sea bottom at those times, or that sudden death sometimes overtook the fauna in the upper waters,

The fresh shale is tough and hard, and I use hard in the strict mineralogical sense. When we drove an adit 100 feet into a hillside along the shale bed, the drill bits lost their sharpness at about the same rate as in granite. Subsequent petrographic study of thin sections revealed the reason for this: instead of being composed chiefly of clay and similar minerals, the most abundant mineral in the shale is quartz.

The shale is so fine grained that no accurate determinations have been attempted of the exact proportions of the different ingredients of the shale. Microscopic study of thin sections, however, shows that the densest parts of the black shale are composed of much bituminous matter, something like 35 percent quartz, perhaps 10 to 15 percent clay, besides pyrite, muscovite mica, and a few minor constituents. Notice that there is fully twice as much quartz as clay.

The quartz grains commonly have maximum diameters of about $0.06 \mathrm{~mm}$, which is the approximate upper limit of silt; from this they range downward to clay-size particles. The quartz appears to have two dominant sizes; one averages about one-fortieth $\mathrm{mm}$ while the other is only one-third that dimension, a little less than a hundredth of a mm. Unless you visualize such sizes better than I do, you may appreciate this comparison: The coarser grains that I mentioned, having average diameters of about $1 / 40 \mathrm{~mm}$, are about one-fourth the thickness of an ordinary sheet of typewriter paper, and the smaller grains average about one-fourth the thickness of the ordinary thin tissue sheets used for carbon copies. The accumulation of such vast quantities of extremly fine grained quartz particles over such large areas, raises interesting questions as to source and the mechanics of transportation and deposition. Thin sections show that many of the laminations in the shale are no thicker than three or four layers of these minute quartz grains, so one can truthfully say that the shale has paper-thin laminations.

The clay mineral is believed, on the basis of X-ray and chemical studies, to be largely illite or hydromica.

The mica is distributed fairly evenly throughout the black shale and has a near-perfect alinement. The degree of sorting in this extremely fine-grained rock is little short of amazing, for many of 
the paper-thin laminae are composed almost solely of quartz, while the adjoining laminae have various mixtures of quartz, mica, and clay. Conodonts, spores, and other detrital fragments are likewise well alined. Both the upper and lower boundaries of these paper-thin layers are customarily abrupt. Such perfection of sorting implies frequent, though gentle, agitation by the water, and frequent agitation, in turn, suggests relatively shallow water.

In many places the upper part of the shale contains phosphate nodules which are either scattered or concentrated in layers, and which are commonly a few inches in size.

Interbedded with the black shale in Tennessee are gray beds which are essentially non-fissile and which contrast markedly with the black shale. These non-fissile gray beds we first termed siltstone, until more careful observation by hand lens and in thin section showed that they are composed of a much greater proportion of clay and less quartz. They are appropriately termed claystone, as they are non-fissile, and have appreciable amounts of clay. The origin of these poorly sorted claystones, interbedded with the well sorted shale, is not easy to explain--either for their different color or their different lithologic character.

In most places a thin bed of black sandstone is present at the base of the shale. This sandstone is commonly less than 1 inch thick; in some places it is hardly more than a film of sand; in some others it is a few inches thick. Normally it rests directly on a clean surface of Ordovician limestone, but locally a fraction of an inch of black shale is below the sandstone, and in some places the sandstone is split by a bed of black shale. At some places the sandstone is entirely missing and typical black shale lies directly on the limestone. This absence or near absence of coarse detritus at the basal contact of the Chattanooga appears to us to have considerable significance.

In one part of Tennessee the shale is underlain by several feet of quartzitic fine sandstone, commonly known as the Hardin sandstone, and in another area it is underlain by the blue phosphate. Some workers have thought that the thin basal sandstone I described a moment ago is a thin wedge of the Hardin, but our detailed studies have shown this is not the case. The Hardin is strictly a local deposit. This brief mention of the Hardin and the blue phosphate is for the benefit of you who may be acquainted with the area; I will not mention those beds again. I repeat that throughout most of the area studied, the black shale is at or very close to the base of the formation. 
In the central Tennessee area the Chattanooga shale has a normal thickness of about 30 to 35 feet. Southward towards Alabama it is thinner, and at the Alabama State line is commonly 5 feet or less thick, or is missing entirely. Northward into Kentucky it becomes thicker. In general, the thickness is surprisingly uniform over fairly large areas, such as one or more counties.

We find that the formation is readily divisible into five lithologic units that can be traced over most of the Eastern Highland Rim of Tennessee, and considerable distances east and west of there. To yield to the temptation to divide a formation only 35 feet thick is to subject oneself to accusations of subdividing beyond the bounds of all reason. Yet we are dividing the Chattanooga shale into two members, much as Campbell divided it. Each of these members has recognizable and persistent subdivisions, and even persistent individual beds. In spite of the seeming absurdity of thus dividing a thin formation, we are doing so in the knowledge that the units can be traced long distances, both lithologically and faunally, can be recognized in the subsurface, and have different economic potentialities.

Briefly, the five-fold subdivision in Tennessee is made possible by the presence within the black shale of two intervals that are notable for the presence of gray claystone beds. One of these, only a few feet above the base of the formation, contains so many gray beds that it is in marked contrast with the overlying and unclerlying black shales, and has been noted by some previous workers. Higher in the formation is another interval containing a few beds of gray claystone interbedded with black shale; this interval is less conspicuous and is overlooked by the casual observer, but it is invariably present throughout a large area, and has an essentially uniform thickness. Recognition of these traceable sub-units has revealed the interesting fact that the successively higher units extend farther and farther south, indicating that from time to time the sea spread further south. This heretofore unrecognized fact is important in evaluating some previous theories, and in speculating on the origin of the shale.

Near the top of the conspicuous gray claystone interval is the most interesting single bed in the entire formation--a bed of bentonite only 1 to 2 inches thick. This bentonite was first recognized by Hass, and subsequently was studied petrographically by C. S. Ross. It is of considerable interest for several reasons: (1) It is the Ordovician type of bentonite (potash bentonite) and this is the highest known stratigraphic occurrence of such bentonite. (2) It is present just below the most conspicuous lithologic break in the entire 
shale sequence, namely the top of the main gray claystone unit; its presence at this position shows that the gray claystone beds over a wide area were formed simultaneously and do not represent a depth facies or any other facies that might have been shifting slowly as the sea encroached on the land surface. (3) It is present just below an important conodont faunal break in the shale, and thus affords an excellent check on of the value of conodonts in stratigraphic correlation; in fact $_{0}$ it affords perhaps the best check that one could ask.

This bentonite and a few feet of the associated gray claystone and black shale are missing in one small area of about 100 square miles, yet there is little other sign of erosion at this position. Apparently gentle submarine planation removed a few feet of the freshly deposited muds, causing a slight marine diastem.

Previously I have mentioned the abrupt contact between the Chattanooga shale and the underlying limestone. I now call your attention to an interesting and abnormal condition at this contact, where locally the black shale lies on an apparent ancient soil or residuum on the pre-Chattanooga land surface. At many places in Tennessee the shale is separated from the limestone by a few inches, or even several feet, of a tan-colored silty clay which is unstratified, quite unlike the Chattanooga shale, locally contains phosphatic and other impurities such as are present in the underlying limestone, and in some places seems to grade into the limestone. In a few places, where this residuum is a few feet thick, a crude stratification has been observed in the upper part, but in most places it is essentially homogeneous. At one outcrop at least 15 feet of this unstratified residuum is present below the Chattanooga.

This material seems to permit of only two explanations: either it represents the insoluble products of the limestone that has been dissolved by ground water since the time of Chattanooga deposition, presumably a recent date, or it represents an ancient soil that was buried by the black muds of the Chattanooga sea. To attribute this material to post-Chattanooga weathering of a fairly pure limestone, presumably by ground-water, would require that a sufficient thickness of limestone be dissolved to leave 5 to 15 feet of residuum, without causing the overlying shale to settle or be otherwise deformed. More likely, such deposits are ancient soils that escaped erosion as the advancing sea spread over the region. Several other facts also lead us to believe that they are pre-Chattanooga soils: (1) Superficially they somewhat resemble modern soils though nothing resembling the upper A and B horizons has been found. (2) Where it 
is present, the rocks above and below show no excessive weathering. (3) In a few places they appear to have been compressed during the accumulation of the overlying shale. (4) They are found only in immediate contact with the base of the Chattanooga shale--nowhere else. (5) The contact with the underlying limestone, where visible, is somewhat pinnacled, and locally appears gradational. We are still not positive that this material is a pre-Chattanooga soil, but no other explanation appears reasonable. Recently Jillson has described old soil at the base of the Chattanooga shale in Cumberland County, Kentucky.

One of the most impressive facts concerning the Chattanooga shale is the near perfect peneplain on which it seems to have been deposited. The shale in Tennessee lies on 23 different formations as mapped by Wilson, ranging in age from Middle Ordovician to Middle Devonian. Nearly everywhere, however, the contact is essentially smooth and shows no more than a few inches of undulation in a single exposure. In many places the underlying formations are gently truncated, so that an angular unconformity of a few degrees is present, yet the contact is essentially smooth. Wherever we have seen the shale, it appears to lie on a peneplain that is remarkable for its smoothness, and is far more perfect than any in existence today. Seemingly, as the Chattanooga sea spread slowly across the countryside, gentle wave action destroyed the soil in most places, removed the fine material, and left only a veneer of the coarser particles. At some places, however, conditions favored a partial preservation of the ancient soil. Thus we find the basal sandstone or the black shale itself resting either on a clean limestone surface, or on an apparent Devonian residuum that locally escaped destruction. The first sediments must have accumulated slowly, close to the shore, in quiet water that may have been hardly more than knee deep.

The Flynn Creek cryptovolcanic structure, exposed in the northeast corner of the Nashville Basin, is of especial interest to students of the Chattanooga shale. This cylindrical or pipe-like structure, about 2 miles in diameter, consists of brecciated rocks of several formations. The fragments range in size from powder to gigantic blocks measurable in hundreds of feet, and seem to bespeak some kind of cataclysm. The origin of such structures is unknown, and we need not digress on that interesting subject. In this area the Chattanooga shale lies directly on the brecciated mass, and erosion has exposed both the shale and the breccia. In the nearby area the shale is about 20 feet thick, but over the cryptovolcanic structure it is about 200 feet thick, the extra thickness being almost wholly in the lowest unit. 
Lithologically this abnormally thick shale differs only slightly, if at all, from the shale of the immediately surrounding area, and Hass has found Late Devonian conodonts in the lowermost beds. Today the abnormally thick part of the shale occupies a basin overlying the fragmental material, and it is understandable that geologists have thought of the muds as accumulating in a crater-like depression. Of real significance, however, is the fact that the shale at the sides has dips toward the center as steep as $20^{\circ}$, yet the shale shows no signs of slumping, flowage, or abnormal coarseness,

It is inconceivable that black muds could have accumulated sn crater sb pes of any such sieepness without slumping and sliding considerably before consolidation, so we are forced to the belief that the muds accumulated on a flat surface that truncated the pipe--in other words, that the pre-Chattanoogapeneplain had beveled the highly jumbled blocks of the cryptovolcano as well as the surrounding countryside, and no basin or crater existed. It is also probable that sediments filling such a crater would contain fragments of the wall rock, yet none are known in the shale. The presence of so much shale having the typical wellsorted characteristics of the normal Chattanooga shale suggests that the mud accumulated on a smooth sea bottom that subsided slowly and was kept filled by the arrival of additional muds. We reason further: if muds could thus migrate over the sea bottom sufficiently to keep this subsiding area filled, without causing the nearby shale to be abnormally thin, those muds must have been subject to more or less continued agitation, not only in the immediate area, but over widespread areas. This and other evidence of more or less continuous, though gentle, agitation and shifting of the mud is one reason why we think the sea must have been shallow.

The Chattanooga shale is overlain throughout Tennessee and adjoining areas by a green mudstone, a glauconitic sandstone, or something in between, that has been termed the Maury shale, the Maury glauconitic sandstone, the Maury member of the Chattanooga shale, the Maury member of the Ridgetop shale, or the Maury formation. Black shale beds, like those of the Chattanooga, are locally present within the Maury. In many places the lower foot or so of the formation is made up largely of phosphate nodules, which superficially give it the appearance of a boulder conglomerate. Although the change from black shale to the greenish or phosphatic beds of the Maury is commonly abrupt, there is no evidence of an unconformity. The unit is only about 2 or 3 feet thick. 
The Maury is overlain abruptly, in large areas, by the Fort Payne chert. This contact is knife sharp, yet, again, there is no evidence of an unconformity. In other areas, notably southern Kentucky, the Maury is overlain by a series of calcareous shales that have been variously termed Ridgetop shale, New Providence shale, and other names, and in many such areas the upper contact of the Maury is so gradational that it can be picked only arbitrarily. No matter what the overlying formation may be, evidence points strongly to continuous deposition from Late Devonian well into Mississippian time. Though thin, the Maury is present at every outcrop we have seen in Tennessee: and southern Kentucky where the suitable interval is exposed. At the few places known to us where the Chattanooga shale is absent, the Maury formation is present and rests directly on the pre-Chattanooga strata.

We come now to direct consideration of the topic I have promised to discuss --the origin of the Chattanooga and related black shales that once covered a large section of the North American continent. The black muds were spread over a sea bottom that extended essentially from New York State to Texas, and from Alabama to the Arctic.

The Chattanooga shale is clearly a marine deposit, as indicated by the presence of linguloid brachiopods, abundant conodonts, and a few other marine fossils. Most writers also agree that such black muds have accumulated in quiet or tranquil water that is low in oxygen.. Sulfur, liberated from sulfates and organic matter poisons the water with hydrogen sulfide, some of which unites with available iron to form pyrite or marcasite in the bottom muds. Only anaerobic bacteria can live in such an environment, and the usual bottom scavengers are absent. Organic matter that sinks from above or drifts in from other areas adds to the sulfurous and generally foul condition of the water. Calcareous shells are dissolved by the acidic water and the precipitation of carbonates is inhibited. Mud and other sediments normally accumulate slowly but imprison large quantities of plant remains and such phosphatic objects as bones, teeth, conodont parts, and linguloid brachiopod shells. On this much there is essential agreement.

Beyond these points of agreement opinions have differed for many years as to the type of sea in which the black muds have accumulated, and there is still no unanimity of thought. It may be that black shales of different regions and of different ages were formed under different conditions. Here however, we are considering only the Chattanooga shale, but the same explanations probably apply in large part of the 
New Albany and Ohio shales of northern Kentucky.

Some writers have argued that the great extent and wide-spread uniformity of the Chattanooga and related black shales, together with the usual absence of ripple marks, cross-bedding, mud cracks, and scour channels, point to their deposition in deep seas, while others have called attention to places where the shale is intimately associated with cross-bedded and ripple-marked sandstones that are clearly of shallow water origin. Some have thought that the finely laminated character of the shale indicates quiet and deep water, while others have argued that it indicates repeated agitation in shallow water. Some have thought that the sulfurous bottom water requires a relatively deep and quiet sea to permit a density stratification whereby bottom waters are not aerated by frequent admixture of water from the upper layers, but other writers have shown that stagnant and sulfurous water can and do exist in shallow areas where the absence of strong tides or currents leaves the water undisturbed, as in some of the Norwegian fjords, the Baltic Sea, Chesapeake Bay, and Barnegat Bay, New Jersey.

It is interesting to observe that some characteristics, such as thin laminations and high organic content, have been used to support both the deep-water and the shallow-water hypothesis.

Before discussing with you the facts that suggest a shallow-water hypothesis, I would like to try to explain several facts which at first suggest deep-water. Chief of these are (1) the relatively uniform fine-grained character of the sediments, (2) the apparent absence of ripple marks, scour channels, and similar shallow-water characteristics, and (3) the presence of black shale, and its implication of stagnant and quiet water.

Consider first the fine-grained character of the sediments. If the only nearby source of sediments in the Chattanooga sea was a widespread peneplain, far more perfect than any peneplain that exists today, if this peneplain was formed largely on limestone and covered by a mantle of soil and vegetation, and if it was drained by small streams, then only fine sediments could be expected to reach the Chattanooga sea. The paper-thin layers of coarse and fine silt, which make up the black shale and which are often interpreted as indicating deep water, are probably better explained by assuming that the bottom waters were subject to gentle but frequent agitation. Such agitation might have been insufficient to aerate the bottom waters, yet have been sufficient to shift the minute particles slightly, transport them short distances, and sort them into 
minute but near perfect laminae.

Consider next the general absence of ripple marks, and similar shallow-water phenomena. The absence of such features appears to result from the fact that most of the muds were too fine-grained to have retained a rippled structure, even if they ever had such structures. In reality, however, the thin sandstone beds that are present locally in the shale, do show small ripple marks at many places. Scour channels, cutting a foot or more into the underlying shale, are present at many places, but are found only when a good outcrop is observed carefully.

Then consider whether or not the mere presence of black shale indicates that the water was stagnant and quiet. Seemingly black muds can accumulate under many conditions where the water is shallow. It probably has to be stagnant, but does it have to be quiet? Twenhofel has described black muds in the Baltic where the water is so shallow that row boats are propelled by the use of poles. Recently Keulegan and Krumbein have shown by mathematical analysis that a gently sloping sea bottom, if sufficiently widespread, will cause incoming waves to lose their force so gradually that at no place do they break or otherwise produce sufficient motion of the water to stir up the bottom muds with any violence. The Chattanooga sea was so widespread and the submerged peneplain surface was so smooth that the conditions postulated by Keulegan and Krumbein may well have prevailed. In other words, if any portion of the Late Devonian sea was deep enough, and sufficiently extensive, to permit the formation of large storm waves, such waves probably lost their force before reaching the region of the Chattanooga shale accumulation. I do not recall having read nor heard this possible corollary of the Keulegan and Krumbein theory, but to me it seems almost inevitable: no matter how extensive a sea, so long as the water is shallow large storm waves can not come into éxistence.

Thus I have attempted to show that the customary arguments for a deep-water origin of black muds are not compelling.

In contrast, I now call your attention to eight circumstances which are not in accord with deepwater hypothesis and which collectively seem to demand a shallow-water origin.

First, the black shale or its basal sandstone lies directly on the smooth surface of the Paleozoic rocks. This condition is so widespread that it is a strong indication that the muds accumulated on the sea 
floor as soon as the land was submerged. Near-shore waves and currents must have been weak as nothing has been seen in the shale that can be interpreted as sand bars or other shore line phenomena. Seemingly the murky shore waters of the sea spread slowly, very slowly, over the smooth land surface that was being gradually inundated, and black muds began accumulating almost immediately. If deep water were necessary for black mud accumulation, we would expect to find some kind of shallow-water deposit below the black shale.

Second, the only coarse detritus at the base of the shale is a bed of fine to medium sandstone commonly a fraction of an inch thick. Quite clearly it represents the coarser and insoluble ingredients which were in the old soil and from which the clay and other fine constituents were winnowed. If it is to be argued that the black muds did not accumulate until the water was deep, whatever is meant by deep, where are the sediments that should have been accumulating during the time required for the water to become deep? If the sea had been there long before black muds accumulated, there should seemingly be a basal concentration of bones, phosphate, spores, wood, conodonts, and other insoluble objects. It is difficult to believe that all the detritus brought into a shallow water sea was swept along the sea bottom so completely out of the region of our investigations that no local patches of the sweepings were left. It is also improbable that the first deposition in deep water would then have been the thin bed of sandstone that is so intimately associated with the black shale.

Third, in many places the shale or its basal sandstone rests on material that appears to be an ancient residuum on the pre-Chattanooga land surface. The material here referred to has not been proved to be a residuum, but the available facts indicate strongly that it is. If it can ever be established, as I think it can, that the black shale lies directly on a residual material, then we have a powerful argument that the mud accumulated close to the shore in extremely shallow water. Any waves or currents strong enough to have swept the sea bottom clean of shallow water sediments during the long ages when the water was becoming deep, would surely have removed all traces of soil. It appears, then, that as the sea spread over the smooth land surface it must have been quiet enough not to dislodge the old soil; instead, sediments began accumulating on the land surface as soon as it was submerged.

Fourth, the perfection of the lamination, the high degree of sorting, and the evidence of 
widespread migration of muds in the Flynn Creek area, all point to oft-repeated agitation of the sediments, as do some other characteristics of the shale. The laminae have such sharp upper and lower limits that simple gravitational settling of muddy water could hardly have produced them. The paper-thin beds, having well-sorted quartz sand, seem to require frequent agitation of the water to shift the particles back and forth and winnow out the clay and mica. In the Flynn Creek cryptovolcanic area we find special conditions that indicate migration of the muds for appreciable distances along the sea bottom. Further evidence that the bottom muds were agitated are fine ripple structures sometimes found in the occasional sand beds that are coarse enough to retain such structures. Also, the one known area of apparent slight submarine planation of the muds, to which I have already referred, indicates disturbance of the bottom water. All these evidences of bottom agitation are perfectly compatible with a shallow-water hypothesis; they fit into a deep-water hypothesis only with difficulty.

Fifth, the black shale beds overlap to extinction so that most parts of the formation can be found lying on the pre-Chattanooga rocks. The successively higher stratigraphic units extend farther south, and a simple explanation of this fact is that the sea was encroaching slowly southward over an ever enlarging area. Proponents of deep-water origin for the shale would have to assume that during all parts of Chattanooga time sediments, from the edges of the sea were being transported over large areas of non-deposition to suitable resting places elsewhere.

Sixth, most of the area in which the shale is typical has been characterized since pre-Cambrian time by lack of deep submergence. Throughout Tennessee and Kentucky, the Paleozoic sequence consists chiefly of fossiliferous limestone and coal-bearing sandstones and shales. It is generally accepted among geologists that the widespread limestone deposits of the eastern interior of the United States accumulated not in deep water, but in relatively shallow seas in which many forms of life flourished. The Nashville and Cincinnati arches have been intermittently rising areas, at least since early Paleozoic time, and it is unlikely that during Chattanooga time, and that time only, they reversed their tendency and sank enough for those areas to be deeply submerged. It is still more unlikely that this region of relative crustal stability sank so rapidly that there was opportunity for only an inch of shallow-water sediments to accumulate.

Seventh, in some other areas Upper Devonian black shale, comparable to the Chattanooga shale, 
is interbedded with sandstone and shale that show unmistakable evidence of shallow water origin. Pepper and deWitt have recently shown that Upper Devonian black shales of New Y rrk State are interbedded with shallow-water sandstones and shales. I have also mentioned that the few sandstone beds present in the Chattanooga shale commonly show small ripple marks. As black muds are known to be accumulating in shallow water today, there seems little justification for ignoring the facts here presented and straining to prove that the muds accumulated in deep water.

Eighth, and last, the succeeding Mississippian sea, generally considered shallow, was far more widespread than the Chattanooga sea. That sea is generally thought, I believe, to have been a shallow epi-continental sea that was clear, and was teeming with life. It is reasonable and logical to suppose that if the Mississippian sea was more widespread, it was also somewhat deeper. If that sea was essentially shallow, it surely suggests that the more restricted Chattanooga sea was even shallower. Quite likely, however, the most significant difference between the Chattanooga sea and the early Mississippian sea was the degree of connection with the open ocean--distinctly limited during Chattanooga time, but unrestricted during Mississippian time. Limited connections with the ocean, especially by way of shallow straits, might have caused the Chattanooga sea to be in a barred basin. Barred basins, like some of the Norwegian fjords, fulfill the requirements for stagnation and black mud accumulation in the simplest manner, and I think it is altogether reasonable to assume that our Late Devonian sea was of such a type.

Each of these eight circumstances suggests that the muds accumulated in a shallow sea. The eight of them combined appear to offer almost compelling evidence that the water was shallow. Several of the circumstances simply will not fit a deep-water hypothesis. On the other hand, the assumption of deep water involves such serious complications in explaining the known facts, that far more problems are created than are settled. As I have also shown, most of the supposed evidences of deep water are not at all convincing, and are easily explained away.

I have mentioned the probable stratification of the water in the Chattanooga sea. The plants and animals whose parts are preserved in the shale could hardly have lived in sulfurous water such as I have described, but required an aerated water. The presence of marine fossils, which could not have lived in the foul bottom waters, indicates that the upper waters of the sea supported several kinds of plant and animal 
life. To do that, the waters must have been aerated by wave action and other contact with the atmosphere. Although fossils are common in the shale, it does not necessarily follow that the upper waters were teeming with life. When it is recalled that 35 feet of black shale represents the entire sedimentary accumulation of a few million years, one realizes that, if the animals were abundant, there should be far more organic remains in the shale than we find. Quite likely life in the Chattanooga sea was difficult and hazardous, and much of the time was sparse. It is easy to see that especially strong storms might have stirred up the bottom water sufficiently to poison the upper waters and kill all the life. Possible evidence of such a series of sudden deaths is the tendency for conodonts and other fossils to be concentrated in certain layers.

An incidental matter of interest is the slowness of accumulation of these sediments. Late Devonian time may well have lasted for some 10 million years. If we use that figure, realizing it may be considerably too large or too small, we find that one foot of compacted Chattanooga shale required about 300,000 years to accumulate. If we assume this shale to have been compressed to about two-thirds its original thickness, we find that the black muds of the Chattanooga sea accumulated at the rate of about 1 foot in 200,000 years. By contrast, the slowest supposed rate of accumulation of the deep-ocean red clays is on the order of 1 foot in 60,000 years. The implication of these calculations is that the Chattanooga shale accumulated only about one-third as fast as the slowest rate we know today. In these calculations, however, we have had to make several assumptions, so the conclusion means little except that it illustrates the extreme slowness with which the black muds gathered on the sea floor.

I have already stated that the source of the vast quantities of silt-size quartz grains requires special explanation. Such silt may well have had three sources: muddy streams from a nearby peneplain far more perfect than any present-day erosion surface, distant sea areas from which the muds were transported in suspension by gently agitated water, and dust storms which brought material from still greater distances. The grains, which are considerably smaller than the thickness of a sheet of paper, are about the size of ordinary wind-blown dust, and it is my personal suspicion that much of the quartz reached the sea during dust storms. On this subject, however, there is much room for argument, and I am not prepared to defend my suspicion, except to point out that lots of dust could fall in an area during the length of time probably represented by the black shales. 
The alternations of black shale and gray claystone, which are characteristic of two stratigraphic units of the shale in Tennessee, are not easy to explain, but may be considered briefly. Such repeated alternations from the foul sulfurous conditions favoring the accumulation of black mud, to oxidizing envirenments permitting the accumulation of light-colored sediments, present a problem to members of either the deep-water or the shallow-water school. Not only are the gray beds lighter in color, but they are finer grained and contain much more clay than do the black beds. They are poorly stratified and are not fissile. The two environments apparently did not exist simultaneously in nearby areas, but each probably existed at a given time over a large area. The various black and gray beds range in thickness from a small fraction of an inch to six inches or more. The alternations were probably not periodic, and attempts to correlate them with astronomic cycles would seem futile. I do not profess to know the cause of these alternations, but I would like to present one idea that has occurred to me as possibly having some merit.

In the semi-isolated Chattanooga sea the water may well have been somewhat less saline than in the ocean, especially if connections with the ocean were distant or were small, and occasional incursions of ocean water of greater salinity and greater density might then have supplied oxygen to the sea bottom. A low divide or a narrow strait between the Chattanooga sea and the ocean, to the south or southeast, might have given the ocean water limited access to the Chattanooga sea. Any geologist, could, if he wished to

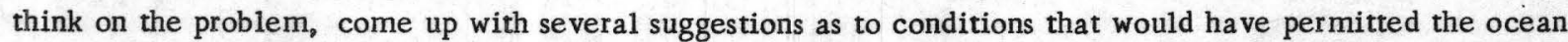
water to come in at irregular intervals--for example: changes in ocean currents, or sedimentary barriers that came and went. If denser ocean water did have occasional access to the Chattanooga sea, it would have underflowed the normal Chattanooga water, without causing an overturn. The absence of fossil-rich layers at the contacts between the black and gray beds suggests that there was no sudden overturn of the water. Other possible explanations of the alternation of these gray and black beds have been considered, but the one I have presented, or some modification of it, seems most worthy of consideration. 